[Collinge, J. (1992). Education in Sweden: Some Recent Developments in Comparison with New Zealand Education in 1992. New Zealand Annual Review of Education, 2, 303-320]

\section{Education in Sweden: Some Recent Developments in Comparison with New Zealand Education in 1992}

\section{JAMES COLLINGE}

$\mathrm{I}^{\mathrm{n}}$ December 1990 the Swedish Riksdag (parliament) made a number of extremely significant policy decisions for the reallocation of responsibilities within the school system. These decisions, in the form of amendments to the Education Act, came into force on 1 January, 1991. This paper examines many of these changes as they affect the compulsory education sector, the upper secondary school and municipal adult education, placing them in the context of the aims and characteristics of Swedish education and making some comparisons with the situation in New Zealand.

\section{Compulsory Education - The Comprehensive School}

Education in Sweden, at all levels, is dominated by two aims, equality and democracy, offering equivalent education to all, regardless of social background and geographical location, with a strong emphasis on democratic aims and procedures. The basic school (grundskola) is a nine year comprehensive school which children attend from the age of seven until sixteen. It is divided into three levels of three years each. There is no streaming, students being kept together in undifferentiated classes, studying a wide range of subjects, including, from the early years, English, which is compulsory for everyone. Specialization is introduced only in the upper grades, and then only gradually and according to the principle of free choice. Three features contrast strongly with New Zealand. First, almost all Swedish youngsters go to the comprehensive school; there are virtually no private schools. Second, there are no
304 James Collinge

public examinations at any stage and, indeed, marks may only be given in the last two years. Finally, all schools are coeducational.

The comprehensive school arose out of the work of a School Commission set up in 1946. This commission, as Wallin (1991) has pointed out, was dominated by Social Democrats and Liberals and its report was much influenced by the experience of the preceding war years and the evils of the Nazi period. The dominant theme of the report was "the democratic society" (p. 143). After a period of experimentation, an Education Act was passed in 1962 which introduced comprehensive schools throughout the country. The reform was completed in 1971-72. Husén (1989) has remarked that a strong feature of the Swedish reform was the high degree of political and public opinion consensus (p. 146).

Although equality is a fundamental aim of the Swedish system, it is by no means certain that all aspects of inequality have been eradicated. Undoubtedly Swedish schools give everybody access to a good education, more working class children have a longer education than previously and there are relatively small differences between the various regions. Streaming, which Nilsson (1989) regards as an important support for a social class based system of education, has been abolished, but he also notes that the development of the school has not been so radical as to threaten in any way the structure of society. Almost all researchers, both Swedish and foreign, agree that the basic social class and gender inequalities have been conserved in spite of organizational change (pp. 359-361). Having said that, however, it must also be pointed out that Sweden maintains a much higher level of general education than was previously the case, with around $95 \%$ of each cohort going on after 16 to upper secondary school.

Another aspect of the Swedish concern for equality can be seen in the education of immigrants. Today, roughly one person in eight in Sweden is either an immigrant or the child of an immigrant. In 1968 the Riksdag decided that immigrant children were to have the chance of instruction in their native language. According to Löfgren (1991), this was based on three principles:

(1) Equality, which means that immigrants are to be given both instruction in Swedish to enable them to play a full part in society and the right to maintain their own language and cultural traditions; 
(2) Freedom of choice to decide to what extent they wish to maintain their own linguistic and cultural identity; and

(3) Partnership which aims at an increased understanding of people with different cultural backgrounds (p. 8).

All students who have a guardian with a mother tongue other than Swedish, which is used regularly and actively in the home environment, are entitled to home language instruction. The municipality is required to make this instruction available provided a teacher can be found and that sufficient students (usually at least 5) are in each group. Home language teachers have, since 1975, received special training, although as we will see later, this is now changing. As an example of what can be achieved, a comprehensive school in Malmö, of 350 children, which I visited several times in 1992, had pupils from 52 different countries, representing 37 different languages. A home language teacher was provided for most of these languages, working with the children on a regular basis.

Löfgren's (1991) research shows that immigrants have roughly the same school success as Swedish students, although there is a problem with older students who arrive in the 7-9 grades. The key factor appears to be proficiency in Swedish, while school success is not greatly influenced by home language instruction. However, in a global society, he points out, there are good reasons for supporting bilingual instruction (p. 84). All immigrant students at both comprehensive and upper secondary school are entitled to Swedish instruction, as are adult immigrants.

The second major aim of Swedish education is to help students grow to be participating members of the democratic society. The comprehensive school is, as Ekholm (1987) notes, constructed so that students throughout their school lives will be stimulated to participate in democracy in an active way (p. 113). Lgr80, the national curriculum of 1980, which is still in operation, has built into it requirements that the planning and design of the school curriculum and the organization of the school should be jointly planned by both staff and students. The fundamental values of a democratic society are to be deliberately promoted and pupils educated to respect them. In contrast to Britain, writes Ball (1988) (and, it must be said in contrast to New Zealand as well), democracy is an active and problematic concept; it is to be presented to children not just as a reified fact of life but as a focus of problems and conflicts and personal commitment (p. 81)

The fundamental democratic structure of the school has been confirmed, and indeed strengthened, in more recent official statements. Proposal 1988/89 presented to parliament emphasizes that it is the task of the teacher together with the pupils to make decisions on the choice of subject matter, planning of work units, the time spent on curriculum themes, sequences, texts and teaching aids, the organization and methods of work and lengths of periods. Pupils, as well as teachers, are to participate in writing the local school plan and in yearly evaluations of the activities (Kallós and Selander, 1992 in press, p. 18).

The motives behind these requirements, write Kallós and Selander, are rather clear cut and simple:

The school is compulsory. The child has to go to school. But that also means that the rights of the child that accompany this obligation have to be defined. Quite compatible with the general democratic view it follows that the child should have the right to participate in

the decisions on how the work in the school is to be organized and carried out (p. 19).

There appears to have been no great disagreement on these issues in either the Committee or Parliament.

It would be wrong, however, to think that all Swedish comprehensive schools are models of participant democracy. Several writers (e.g., Ekholm, 1987; Husén, 1989; Berg, 1992), have pointed out that schools take a long while to change, that tradition is strong and that, whatever the curriculum may say, many teachers take some time to learn to operate in ways that are unfamiliar to them. Nevertheless the intention is clear, some schools no doubt do achieve considerable success in giving their students influence over educational planning and there is a very real possibility that more will be done as a new generation of teachers, training in a new system which will be discussed later, come into the schools.

\section{Post-Compulsory Education - the Upper Secondary School}

At the age of 16 , some $95 \%$ of students upon completion of their nine years compulsory education, transfer to the Upper Secondary School 
(Gymnasieskola), which they attend for two, three or occasionally four years. This institution was created through the amalgamation of several other types of post-compulsory school and offers a number of "lines", both vocational and more general, including preparation for higher education. Upper secondary schools are established in municipalities large enough to support them and are open to students from other municipalities. All young people, up to 20 years of age, have a right to attend, although not all necessarily are accepted into their first choice of study. Parliament requires, in its guidelines, there to be a total number of places corresponding to $100 \%$ of all 16 year olds, although as "mature" applicants can also attend, there are, in reality, more places than this (Stenholm, 1984, p. 67).

In neither the compulsory nor upper secondary school are there comprehensive examinations to serve as a basis for streaming students into particular lines of study, academic or vocational. All compulsory school leavers may apply for upper secondary school, regardless of what subjects they have taken at a previous level. In accordance with the basic egalitarian and democratic principles of Swedish education, all students have a free choice of specialization according to their interests. Most appear to get their first choice, although in some special areas, such as music, there is fairly rigorous selection. Opper (1989) has noted that the most consistent force upon students' decisions appears "to be the influence of the familiar - in fact very much the family environment" (p. 148). Thus there is no doubt that class and gender factors enter into a student's selection, although there are vigorous efforts on the part of authorities to encourage females to enter typically male dominated subject areas and vice-versa.

Upper secondary education is completely free of charge for all students (as is, incidentally, university education) and, a part from a few specialist materials, all books and other teaching equipment are also provided. Students living more than $6 \mathrm{kms}$ away from the school qualify for a state travel allowance and, in many municipalities, meals are provided free, as they are in the compulsory school. Students between the ages of 16 and 20 receive a grant comparable to the child allowance which is currently around $9000 \mathrm{kr}$ annually (approximately $\$ N Z 3,000$ ) (Statistics Sweden, 1991). This grant is not subject to a means test. Supplementary benefits for boarding and travel are also available. Students aged 20 or over attending upper secondary school are entitled to essentially the same kind of benefit.
Currently there are a number of changes in operation aimed at strengthening the upper secondary school offering. All programmes (the term "line" is to be discontinued) will be three years long, irrespective of the choice students make. According to the Ministry of Education policy document "Growing with Knowledge" (1991c), the new system is designed to be more flexible than previously and to provide wider programmes in both general and vocational subjects. The proposal is to have 16 nationally determined three year programmes, all of which will contain a core of subjects; Swedish, English, civics, religion, mathematics, science, sports and health and arts. At least $15 \%$ of the vocational national programmes will be allocated to a place of work.

There is not space here to go into the details of these programmes, but it must be noted that every municipality will be obliged to provide a comprehensive selection of the national programmes for all under 20 year olds and, in addition, individual programmes for those who do not receive a place. This could also include special arrangements for the handicapped. The programmes will remain free of charge and students will have access without cost to all books, tools and other aids "necessary for a modern education" (Ministry of Education, 1991c, p. 5). These changes are to be implemented so that all admissions to the upper secondary school during the year 1995-6 are based on the new programmes, although admission may start in 1992-3. The present system will be phased out in 1993-4.

As is always the case in Sweden, the new proposals have been drawn up in accordance with fundamental democratic values, and the rights of students to influence developments is provided for in legislation. Thus democratic methods of working are encouraged; students are given the opportunity to express their own views and to participate in democratic decision-making processes concerning their own education; and civics, in which the basic questions of democracy and co-determination are deal with (p. 11), is a core subject in all programmes.

The goals, and guidelines of the upper secondary school are, of course, determined by the government. In "Growing with Knowledge" a number of "common starting points" (pp. 11-12) have been identified. These include knowledge of the environment, ethical and moral questions, and strengthening of the historical dimension within the framework of different subjects, including political, economic, cultural and religious issues for students within the vocational programmes. 
New supplementary training programmes for teachers in the upper secondary schools will be necessary, with municipalities being given full responsibility for making sure these take place and that teachers have access to them.

\section{Adult Education}

Adult Education, as Marklund and Bergendal (1977) point out, has a long tradition in Sweden going back to the first Folk High Schools in 1868. During the 1960s, however, the growth in the school system resulted in a generation gap and it was consequently regarded as only fair that the older generation, who had missed out on a full education under the previous system, should be entitled to more. Legislation was thus passed in 1968 making municipal authorities responsible for a wide range of adult education provisions, which include basic education for both Swedish and non-Swedish speaking persons. In addition, there are numerous, well-established adult education associations operating "study circles", an important form of popular, informal education, which are entitled to state assistance. Mention must also be made of labour market training, which aims at providing vocational education to the unemployed or people in danger of losing their jobs. Some idea of the importance of this last form can be judged by the fact that since the 1970s, Sweden has undergone a major structural adjustment without a period of mass unemployment.

Perhapsindicative of how radical the transformation of the economy has been is the fact that whereas in the early 1970s Sweden had the second largest shipbuilding industry in the world, by the mid-1980s it had moved out of shipbuilding altogether, having trained, retrained and relocated the substantial work force without the prolonged high unemployment associated with ship yard closures elsewhere (Standing, 1988, p. 94).

It has been estimated that approximately one Swedish adult in every three participates, at any one time, in some form of adult education (NBE, 1986), although Rubenson (1989) believes that the gap between the educated and under educated has not decreased and will not without "earmarked allocations to clearly defined target groups" (p. 135). Nevertheless, in comparison with other countries, such as Britain and New Zealand, adult education appears to be highly developed, extensive and lavishly funded.
The Swedish concept of educational disadvantage, in the sense of not having completed the full cycle of basic and vocational education has no meaningful equivalent in British political discourse (Ball, 1988, p. 82).

Unfortunately there is no space here to go further into the complexities of this most important and fascinating aspect of Swedish education. (For further discussion see Ball and Larsson, 1989). Currently the adult education system is being expanded, including basic education for immigrants, a new type of Basic Education starting 1992-93 aimed at giving adults a broad general competence for working and social life, as well as a basis for further study; and adult education for the handicapped. These will be provided by the municipalities free of charge.

\section{Recent Structural Changes}

Until recently, Swedish education was administratively highly centralized, the National Board of Education being the central authority responsible for the comprehensive schools, upper secondary schools and some adult education. Below this, 24 County Education Committees supervised the schools in the counties and distributed state grants. However, in many respects, the school system was becoming a municipal responsibility. Marklund and Bergendal (1979) regard this as "one of the significant steps toward a democratization of education through increased local influence" (p. 27) and note that the balance between State and municipal influences was a much debated topic in the 1960s and 1970s. However, the aim was to achieve a uniform structure in the education system, with a number of rules, in order to achieve equal educational standards.

In 1991 this system of responsibility for the schools was radically altered. Parliament decreed that national control by means of detailed rules was to be superseded by a system giving much greater scope for decision-making at a local level. On 1 July 1991, the National Board of Education and the County Education Committees ceased to exist and a new National Agency for Education, Skolverket, was formed. Control of school activities was now to be carried out through determining more precisely the goals, guidelines and contents of teaching, while giving considerably increased responsibility to the municipalities for deciding how these goals were to be realized. Money allocated from the state is now given as a lump sum which the municipality is free to allocate and 
distribute as it sees fit. The detailed regulations which earmarked the use of state funds have been abolished. Thus the municipalities now have complete and undivided responsibility for school activities and for the achievement of targets set by Parliament. Some of these "kommuns" are quite small; about $80 \%$ of them have populations of fewer than 20,000 and the median size is $16-17,000$ (Kogan, 1992, p. 18).

The State grant provides the total state support for the comprehensive school, the upper secondary school and municipal adult education. In line with the Swedish concern for equality, however, a number of special factors are to be taken into account in calculating the grant. School activities in non-urban areas are accepted as being more costly per student than in densely populated areas. The calculation model also takes into account the needs of municipalities that have a relatively greater number of immigrant students. Other factors include the proportion of low educated who may need Basic Adult Education, the proportion of job seekers and families on grants.

The same goals and guidelines will apply to all schools in the country. Equality is still a basic aim while the Education Act safeguards fundamental democratic values. Teachers are employees of the municipality, although the law requires that they hire only teachers who have undergone Swedish or equivalent Nordic teacher training. One interesting feature is that the regulations specifically prevent the School Board from intervening in methodological or pedagogical matters of a professional kind: the task of choosing materials and methods in teaching is specifically regarded as the province of the teachers and students (Ministry of Education, 1991a, 2.3). In marked contrast to New Zealand, the regulations guarantee parents no specific role. The Principal has a duty to keep parents informed, but their influence on the school depends very much upon local decisions. Thus, in some places, there may be movement towards parent involvement but not uniformly throughout the country (Bertil Gran, private conversation).

Skolverket, the new central agency responsible for education, has, as one of its major functions, the task of redrafting the national curriculum to replace the current one, Lgr80. It is interesting to note Kogan's (1992) remark from a British perspective, that the existence of a Läroplan, or national curriculum, does not in Sweden cause a tremor of dissent, even given radical change in political control at the centre:

whatever caused Swedish leaders to make the changes did not lead

them to change everything, least of all the prevalent attitudes at all points in the education system toward basic Swedish values. Swedes remain determined that all will have access to quality education in what many refer to as the national school (p. 2).

Skolverket also has responsibility for the follow-up and evaluation of public sector schooling. In contrast to the previous situation which saw information collected by a number of different agencies, the new body now has sole responsibility for ordering figures on the school sector. There are two interconnecting aims here: the promotion of development at the local level and the development of a steering instrument to manage the state-municipality relationship (Skolverket, 1991, p. 4). The procedure is to be in three parts: the municipality will be the primary source of information, Statistics Sweden will process the basic data and Skolverket will then be responsible for analysis, presentation and feedback of information to the municipalities. A national assessment programme for the compulsory school was undertaken in Spring 1992. This programme, in which teachers and students were active in the evaluation process, placed an emphasis on qualitative data and process studies. At the time of writing the results were not available (Oquist, 1992, p. 2).

There is an interesting question, however, about the role of Skolverket in this evaluation exercise. To a large extent it is dependent upon the schools and yet it wishes to remain independent of them and keep its objectivity. To date it has resisted the opportunities to work with the municipalities in the schools (Lars Stensborg - private conversation). How, though, do they get to know what is going on in the schools? As Thorbjörn Levin, Skolverket officer in Malmö, told me, Skolverket has a new task, "to know about the schools".

A fundamental question, which Berg (1992) raises, is why has this intense process of decentralization, which has replaced a detailed rule system with vaguer framework rules, been undertaken. One of the explanations he offers is that decentralization moves conflicts, which make clear-cut state steering of the school well-nigh impossible, away from the central to the local level. Decentralization thus involves a shift in power from state to society, a process of "societification of the state". However, as Berg points out, the state may reclaim, or even increase, its power by various control measures, such as the national programme of evaluation referred to above.

The current Swedish government is very much concerned with introducing the notion of choice into education (Kallós and Selander, 
1992, p. 35). In contrast with New Zealand, Sweden has virtually no private schools, although the conservative government clearly supports an increase in their numbers. However, all proposals for new private schools will have to be evaluated by Skolverket. If they are accepted, then they will have the right to be funded, as is the case in neighbouring Denmark, or, even more so, in Holland, which has some 70\% privatization (Psacharopoulos, 1992; Bjerg, 1991; Hellinger, 1991). It remains to be seen whether Skolverket will find acceptable proposals from small, fundamentalist religious sects, or from immigrant groups whose views may well contradict basic Swedish values of equality and democracy, e.g., with respect to coeducation and the education of girls. Parental choice may be exercised to some extent between comprehensive schools, provided it does not affect the basic right of other students to go to the school closest to their home. Of course, in the absence of public examinations, schools cannot be compared, as they are in New Zealand, by the crude publication of the percentage of results in School Certificate or Bursary examinations in the daily press.

A further element of choice is to be introduced with respect to the age at which the child starts school. Compulsory attendance starts in the Autumn term when the child becomes seven years of age, but now parents may choose to enter their child at the age of six. During a transitional period, the final decision will lie with the municipality, but from 1 July 1997 all six year olds will have the right to enter school. If the New Zealand experience is anything to go by, almost all children will be going to school at six

\section{Teacher Education}

In the Swedish education system, considerable emphasis is placed on the professional role of teachers. Ekholm (1987) has remarked that Swedish teachers are used to being left alone and being trusted (p. 116) and this is maintained in the current changes which place all pedagogical questions in the hands of the professionals. The process of curriculum planning in the compulsory school is marked by an emphasis on teamwork among teachers, the involvement of pupils in the planning and evaluation of educational activities, and a concern for the social relevance of education coupled with a demand for high standards. This as Opper (1986) points out, sets a very high level of ambition for the professional competence of teachers, which includes experience in collective forms of management and conflict resolution (p. 139). A curious feature of the comprehensive school reform, however, is that teacher education remained unchanged as a result until the mid 1980s.

Although the comprehensive school was designed as essentially a single nine year school, the teachers have been, until now, divided into two categories, class teachers and subject teachers. To some extent these corresponded to the primary/secondary division in New Zealand, receiving different training and belonging to different unions (Boucher, 1985). The two types of teachers in fact represented two entirely different traditions, the class teachers who had responsibility for the lower grades having their roots in the mass schooling that developed in the 19th century, and the subject teachers who had their antecedents in the academic tradition, with strong attachment to the universities (Kallós and Selander, 1992). In other words the reform from the parallel system to the comprehensive system to a large extent kept the existing divisions among teachers intact.

During the spring of 1985, Parliament decided to reform teacher education to end the differentiated system. The resulting programme is designed to train teachers for two concentrations, Grades 1 to 7 and Grades 4 to 9 , but not in two separate programmes; as far as possible all candidates will take courses in common. All teachers will have at least $3^{1 / 2}$ years of training and the 4 to 6 grade teachers will be trained to teach 3 or 4 subjects rather than 2 as at present. The overlap between the two groups will give some flexibility in the schools; no teachers will be trained exclusively for the younger children, Grades 1-3. The new arrangements also allow for Grade 1 to 7 teachers to follow their classes through for some years, a controversial procedure, although it must be noted that Swedish teacher/student ratios frequently allow more than one teacher to be attached to each class. The new proposals received considerable opposition, particularly from the subject teachers' union (Opper, 1986, p. 145; Kallós and Selander, 1992, pp. 20-23); nevertheless the bill finally went through and the first group of teachers trained in the new system graduated in June 1992.

The new teacher education will undoubtedly produce, as Kallós and Selander point out, a more unified teacher corps for the comprehensive school with possibly increased qualifications overall; at least that is the intention. The old system, with its detailed regulations, restricted the teacher's role, but the new one will change the nature of teachers' work quite substantially, although it is always an open question as to whether 
it will increase teacher autonomy or local political/administrative power. Opper (1986) is in no doubt though, that the intention of the reform is, in part, "to prepare teachers for the extensive locally initiated planning and development work expected of them, as well as enhancing the quality of compulsory education by strengthening the educational background of its teachers" (p. 144).

In-service education has also been changed to some extent. This is now totally in the hands of the local authorities, who nevertheless are obliged to ensure that there is access to supplementary training of good quality in all parts of the country. A major source of in-service training will be higher education, the local authorities buying courses from the universities. Previously the system allowed for 5 study days when the school was closed, together with other courses with release time, relieving teachers being provided. This system has now more or less been abolished and teachers are obliged to engage in in-service training for 3 weeks every 3 years, outside of the school term, a decision which has, in effect, prolonged the teachers' year and which, predictably, provoked strong opposition from them (Bertil Gran - private conversation). The 5 study days with the school closed have been kept.

\section{Conclusion}

Sweden, a western democracy with a small population (8.3 million), makes, in some ways, a better comparison with New Zealand than much more populous countries such as Britain or USA. Both countries were also welfare state pioneers, although, as Davidson (1989) has shown, the two models have diverged considerably, so that New Zealand, with its reduced spending, can now be described as a "residual" welfare state, with a preference for targeted income-tested benefits and social rights which "are unusually under-developed" (Esping-Andersen, 1990, p. 75). Sweden, on the other hand, with its long, relatively uninterrupted period of Social Democratic government, has, despite profound economic problems, kept its social welfare system intact and today still presents a model of a universalist system, where means testing and other ways of restricting access are kept to a minimum, so that all citizens can "claim most benefits as of right" (Davidson, 1989, p. 205) Of course the high Swedish tax burden has been regarded as a disadvantage of the system. Other attacks on the Swedish welfare state, such as the supposed high rate of suicide, alcoholism and family breakup "can be dismissed as based on ignorance and myth", using partial, false or misinterpreted statistics (Milner, 1989, p. 205).

It would be tempting to present Sweden as a kind of educational utopia. We have been looking at a country based on strong democratic and egalitarian principles, which, even if it has not succeeded in ridding itself of social class inequalities, gives all students a high level of education without the sense of failure induced by examination systems; which, as a consequence, has more than $90 \%$ of its 18 and 19 year olds in worthwhile, full-time education; which makes remarkably generous provision for the needs of its large number of immigrants; which has a widespread and well-funded system of education for the handicapped; which has an extensive system of education and labour-market training for adults; and which has conditions of work that many New Zealand teachers these days could only marvel at. However, as Peddie (1992) has noted, useful as comparative analysis is, we must look at the total context in which the policy is operating, which means the cultural, social and political setting, as well as the nature of the school system. It must also be pointed out that the Swedish system is not without its local critics, not only those who bemoan lack of standards compared with the old, selective system, but also those who express concern at an economic system in which over $60 \%$ of GNP is spent in the public sector (Torsten Husén - private conversation). The comparative figure for New Zealand is around $40 \%$ (Rudd, 1990, p. 85).

Many Swedes complain of the pace of change in the structure of their education system at the moment and there is no doubt that the move from a centralized rule-based system to a decentralized goalbased one is quite radical. Swedish educational reform, however, since the 1940s seems to the outsider to be always thorough and researchbased and the present changes seem to be no exception. In many ways they appear to be the logical continuation and extension of decentralizing moves going back to the 1970s. It is doubtful whether Sweden faces anything like the rapidity of change and the bewildering shifts of direction that New Zealand education has undergone over the past four years; there would appear to be no Swedish parallel to the following statement by Roger Douglas, former Minister of Finance;

Implement reform by quantum leaps. Moving step by step lets vested interests mobilize. Big packages neutralize them. Speed is 
essential. It is impossible to move too fast. Delay will drag you down before you can achieve your success. Once you start the momentum rolling never let it stop. Set your own goals and deadlines. Within that framework consult in the community to improve detailed implementation (Lauder, 1991, p. 8).

As Lauder goes on to note "the essential qualities of a democracy, those of participation, tolerance, respect for other's point of view are missing from this credo" (p. 8).

Within the Swedish system there are a number of hindrances (or safeguards, depending on your point of view) which prevent too rapid changes, such as regulations, particularly those concerned with equality, and, of course, a political system of proportional representation which means that compromises constantly have to be reached. The Conservatives, for example, would have liked a form of teacher training which emphasized the subject degree rather than the present, entirely integrated system, but the other parties in government would only accept this as an experiment on a small scale. Similarly the agrarianbased Centre party has blocked moves towards a simple per-student funding system on the grounds that this would disadvantage the rural sector (Bertil Gran - private conversation). A move by the Conservatives to have marks in the lower grades was also defeated (Björn Beckman private conversation). Nevertheless, several teachers I spoke to in Sweden expressed fears for the future, that bulk funding would mean staffing cuts (although Sweden would have a long way to go before it reached New Zealand's teacher/pupils ratios) and also fears that the home language programmes might be slashed. The extent to which bulk funding is devolved to the school level is a matter for the municipalities to decide. It must be noted that without a Board of Trustees, in the New Zealand model, considerable responsibility or power is placed on the school leader or principal. In recognition of this, Sweden has an extremely comprehensive School Leadership Education Programme (SLEP) in four phases: Recruitment, Introduction which gives the newly appointed principal an overview of the job, Deepening, a central three year programme of on the job training, and finally, In-service Training, provided by the kommuns with help from universities and other consultants which might provide a great variety of courses to meet the leader's needs as they arise. SLEP is compulsory for all school leaders. Undoubtedly there will be changes in this programme with new responsibilities for the steering of the school, (Kogan, 1992) but nevertheless SLEP will remain as another example of the thoroughness and professionalism with which the Swedes approach education.

One thing Swedish teachers do not have to put up with is the thoroughgoing attack on the teaching profession which New Zealand teachers frequently face, whether this takes the form of Treasury strictures on "provider capture" with teachers seeking "to defend and develop their own interests" (Treasury, 1987, p. 277) or the more crude "teacher bashing" which politicians, journalists and business leaders indulge in, often in the daily press. Teachers in Sweden appear to be highly regarded as professionals who have been well-trained and are thus trusted and respected. As we have seen, although it does not always work out in practice, the Swedish system is based on fundamental principles of equality and democracy, and teachers are expected, indeed required, to co-operate, not only between themselves, but also with their students. In contrast, a just published (November 1992) report on shared decision making in New Zealand schools, places great emphasis on the need for collaborative decision making structures involving all staff, but barely mentions students (Hall, 1992).

But then co-operation, collaboration and democratic participation seem to be at the very heart of "the Swedish way". Recently, faced with an economic crisis, the Coalition government has collaborated with the Social Democratic opposition to make a few changes in the social welfare system (very minor changes, it must be said, compared with what New Zealand has gone through in the last couple of years). No doubt the Social Democrats have been criticized for this by some of their supporters; no doubt they also won some concessions in return. But we have here the spectacle of Government and Opposition co-operating in the face a crisis: now that would be something in present-day New Zealand.

\section{References}

Ball, S. J. "Costing Democracy: Schooling, Equality and Democracy in Sweden" in H. Lauder and P. Brown. (ed) Education in Search of a Future. London: Falmer, 1988, pp. 75-90.

Ball, S. J. and Larsson, S. (eds). The Struggle for Democratic Education: Equality and Participation in Sweden. London: Falmer, 1989.

Berg, G. "Changes in the steering of Swedish schools: a step towards 'societification of the state'", in Journal of Curriculum Studies, Vol. 24, No. 4, 1992, pp. 327-344. 
Bjerg, J. "Provincial Reflections on the Danish Education System", in Compare, Vol. 21, No. 2, 1991, pp. 165-178.

Boucher, L. "Teacher Unions: Some Swedish Perspectives" in M. Lawn (ed), The Politics of Teacher Unionism: International Perspectives. London: Croom Helm, 1985, pp. 141-157.

Davidson, A. Two Models of Welfare. Stockholm: Acta Unversitatis Upsaliensis, 1989.

Elkholm, M. "School Reforms and Local Response: an evaluation of school reviews in 35 school management areas in Sweden, 1980-1985", in Compare, Vol. 17, No. 2, 1987, pp. 107-118.

Esping-Anderson, G. The Three Worlds of Welfare Capitalism. Cambridge: Polity Press, 1990.

Hall, R. Managing Today's Schools: The Case for Shared Decision-Making. NZ Institute for Social Research and Development, 1992.

Hettinga, C. Education in the Netherlands. Malmö School of Education, 1991.

Husén, T. "The Swedish School Reform - exemplary both ways", in Comparative Education, Vol. 25, No. 3, 1989, pp. 345-355.

Kallós, D. and Selander, S. "Teacher Education and Teacher Work: reform strategies and professional reorientation - The Swedish Case", in press, 1992.

Kogan, M. School Leader Education in Sweden. Stockholm: Skolverket, 1992.

Lauder, H. Tomorrow's Education, Tomorrow's Economy. NZPPTA, 1991.

Löfgren, H. Immigrant Students in Sweden: a comparative study between different immigrant groups and a sample of Swedish Students. Malmö: School of Education, 1991.

Marklund, S. and Bergendal, G. Trends in Swedish Educational Policy. The Swedish Institute, 1979.

Milner, H. Sweden: Social Democracy in Practice. Oxford: Oxford University Press, 1989.

Ministry of Education, Sweden The Responsibility for Schools, a Government Bill and the decisions of Parliament in December, 1990, 1991a.

Ministry of Education, Sweden A Reform of the Education System: A Government Bill and the decisions of Parliament in June 1991, 1991b.

Ministry of Education, Sweden Growing with Knowledge: a reform of upper secondary and municipal adult education in Sweden, 1991c.

Nilsson, I. " 'A Spearhead into the Future' - Swedish comprehensive school reforms in foreign scholarly literature 1950-1980", in Comparative Education, Vol. 25, No. 3, 1989, pp. 357-362.

Opper, S. "Organisation of Teacher Training in Sweden Catches up to the Compulsory School", in European Journal of Education, Vol.21, No. 2, 1986.

Oquist, O. Swedish National Assessment Program for the Compulsory School, Skolverket, 1992.
320 James Collinge

Peddie, R. "Comparative analysis essential when introducing overseas policies", in Dominion Sunday Times, October 4, 1992, p. 12

Psacharopoulos, G. "The Privatization of Education in Europe", in Comparative Education Review, Vol. 36, No. 1, February, 1992, pp. 114-119.

Rubenson, K. "Swedish Adult Education Policy in the 1970s and 1980s" in S. Ball and S. Larsson (ed), The Struggle for Democratic Education: Equality and Participation in Sweden. London: Falmer, 1989, pp. 117-136.

Rudd, C. "Politics and Markets: The Role of the State in the New Zealand Economy", in M. Holland and J. Boston (ed), The Fourth Labour Government: Politics and Policy in New Zealand. Auckland: Oxford University Press, 1990, pp. 83-100.

Skolverket A result-oriented follow-up system for the school sector in Sweden, 1991. Standing, G. "Training Flexibility and Swedish Full Employment", in Oxford Review of Economic Policy, Vol. 4, No. 3, pp. 94-107.

Statistics Sweden, Sweden in Figures, 1991.

Stenholm. B. The Swedish School System. The Swedish Institute, 1984.

Treasury (New Zealand) Government Management Brief to the Incoming Government 1987: Volume II Education Issues. Wellington: Government Printer, 1987.

Wallin, E. "The Comprehensive School - the Swedish case", in European Journal of Education, Vol. 26, No. 2, 1991.

In addition I have drawn directly on private conversations with the following people:

- Björn Beckman, Department of Political Science, Lund University, 16 June 1992.

- Bertil Gran, School of Education, Malmö, 23 April 1992.

- Torsten Husén, Institute of International Education, Stockholm University, 18 May 1992.

- Thorbjörn Levin, Skolverket, Malmö, 29 April 1992.

- Lars Stensborg, Kommunförbundet, Stockholmslän, 19 May 1992.

Acknowledgments

The research on which the article was based was made possible by a Guest Scholarship from the Swedish Institute for three months, A pril to June, 1992. My thanks are also due to my colleagues at the School of Education, Malmö for their hospitality and help during my period there as Visiting Scholar

\section{The author}

James Collinge is a Senior Lecturer and Associate Dean (Students) in the Education Faculty at Victoria University of Wellington. In 1992 he spent several months in Sweden on a Guest Scholarship from the Swedish Institute as a Visiting Scholar at the Malmö School of Education. 